\title{
Academic Endowments in the United Kingdom - Do They Make a Difference?
}

\author{
Aljoša Šestanović ${ }^{1}$, Fayyaz Hussain Qureshi ${ }^{1}$ \& Sarwar Khawaja ${ }^{1}$ \\ ${ }^{1}$ Oxford Business College, 65 George Street, Oxford, UK \\ Correspondence: Fayyaz Hussain Qureshi, Oxford Business College, 65 George Street, Oxford, United Kingdom. \\ E-mail: fayyaz.qureshi@oxfordbusinesscollege.ac.uk
}

Received: December 5, 2021

Accepted: December 30, 2021

Online Published: January 4, 2022

doi:10.5430/irhe.v6n4p11

URL: https://doi.org/10.5430/irhe.v6n4p11

\begin{abstract}
This paper analyses the role and significance of the endowments for the UK higher education system. We have systematised the metrics commonly used to measure the performance of the academic endowments. To collect the data about universities and colleges, we exploited the data provided by the HESA (Higher Education Statistics Agency) that collect and disseminate UK higher education data and the data provided by the Charity Commission for England and Wales. The size of the university and colleges endowments is valued using their respective financial statements, using endowment reserve account of the balance sheet.

The academic endowments linked with the UK universities and colleges are estimated to be worth $£ 15.8$ billion in 2020. According to the number of the endowments linked with universities and colleges endowments, they play a significant role in the UK higher education system. However, there is a notable difference concerning endowment size between the few most reputable academic institutions and other universities and colleges. For example, the two largest endowments (the University of Oxford and the University of Cambridge with accompanied colleges endowments) in 2020 had a share of $75 \%$ measured by the size of the endowment assets. Moreover, this $75 \%$ has been stable during the last several years.

In addition, the UK academic endowments are much smaller than their US counterparts and thus generally have lesser significance for the UK higher education system, while they may play a significant role for particular institutions. The endowment size per student has also been much smaller in the UK than in the US. Except for the six universities and colleges, the share of the income coming from endowments and donations in the total income has been relatively low, $2 \%$ or less. Considering the long history and tradition of the endowments in England, their role in the UK higher education system is deeply rooted. However, with their historical performance and significance for some higher education providers, there is an opportunity for a more prominent role in the future.
\end{abstract}

Keywords: endowments, academic endowments, universities, colleges, higher education

\section{Introduction}

The endowments are vital funding sources for many non-profit organisations, such as universities and colleges, museums, hospitals, and others involved in charitable activities. For example, universities and colleges in the United States heavily rely on the endowments' support for strategic and operating goals. Although endowments are less significant in other higher education systems than in the US, they have been prominent participants of the higher education system in some countries, at least as a traditional part of the education system. In addition, although much smaller in size than the US endowments, endowments provide crucial financial support for some higher education providers in the UK. (Note 1)

This paper focuses on the university and college endowments in the UK. According to the data provided by the Charity Commission for England and Wales (Note 2), 86,428 registered charities operate in general education and training (including universities and colleges registered as charities). However, only 5,108 of them have an income of $£ 1$ million or more. Furthermore, only 24 universities and colleges in the UK have endowments of size over £50 million. The total size of the university and colleges endowments in the UK in 2020 is estimated at $£ 15.8$ billion. (Note 3)

The endowments have a long history. One of the earliest records of the endowment support was Stift Klosterneuburg, 
a monastery near Vienna endowed by Markgraf (Count) Leopold III in 1114 (Franz \& Kranner, 2019). Although the endowment concept originated in England in the fifteenth and sixteenth centuries, the development of endowments for higher education institutions is an American phenomenon (American Council on Education, 2021). (Note 4) The underlying reasons for the endowments playing a significant role in the US are severalfold. According to Franz \& Kranner (2019), the first reason is that the private sector has a leading role in higher education in the United States. The second reason is the more lenient regulation of the endowments in the United States. Third, the United States has a strong private philanthropic culture. In addition, the lower use of endowments in England can be attributed in part to the mixed economy expectation that public subsidy will provide support for core expenses (Arts Council England, 2010).

Before taking a closer look at the performance metrics of the academic endowments in the UK, in the first section, we outline several definitions and purposes of the academic endowments. In the following section, we have systemised and discussed the academic endowments' performance metrics. Before the conclusion, we calculate and analyse the relevant performance measures and make specific observations. The last section is the conclusion, where we reflect on the main features and significance of the endowments for the higher education system in the UK.

\section{The Definition and Purpose of the Academic Endowments}

In general, endowments are charity-purpose investment vehicles consisting of a pool of aggregated assets constructed on general portfolio management principles and managed by asset management professionals. The main objective of the endowments is to produce target returns commensurate with the undertaken risk and other investment constraints, in line with an adopted investment philosophy and charitable mission. Maginn et al. (2007) specified that the term endowment has two related but distinct meanings. As commonly understood, an endowment is simply the long-term investment portfolio of a charitable organisation. Legally and formally, however, the term endowment refers to a permanent fund established by a donor with the condition that the fund principal is maintained over time. (Note 5)

There are many definitions of endowments serving the educational sector. The simplest one is that the endowment is an aggregation of assets invested by a college or university to perpetuate its educational and research mission (American Council on Education, 2021). Endowments - whether held by colleges or universities, museums, churches, hospitals, or other charitable organisations - are pools of privately donated funds that are invested in supporting the institution in perpetuity (Association of Governing Boards of Universities and Colleges, 2019). (Note 6) The Universities UK (2019) defines an endowment fund as a form of charitable trust retained for the institution's benefit. Thus the primary purpose of creating an endowment is to be invested so that the total asset value will increase and create another source of income for the university.

Franz \& Kranner (2019) summarise the unique characteristics of university endowments: (1) the permanent transfer of wealth from donors to the institution, (2) their perpetual time horizon, and (3) the special network a university enjoys through its stakeholders.

The endowments may be classified according to two criteria: (1) whether the capital can be converted into income and (2) whether the donor stipulates some spending restrictions. According to the first criterion, if an endowment prohibits converting the capital into income and capital must be held indefinitely, it creates a permanent endowment fund. Otherwise, if the endowment capital can be converted into income, it creates an expendable endowment. According to the second criterion, permanent endowments are split between restricted and unrestricted. Notably, if investment income earned by the endowment assets is restricted in use, it becomes a restricted permanent endowment. Otherwise, it is an unrestricted permanent endowment.

The purpose of the endowments is closely aligned with the institutional mission and strategic goals, including the desired level of charitable activities. In general, the primary purpose of an endowment is to be invested so that the total asset value will increase and create another permanent source of income for the university.

Traditionally, educational institutions have used endowment funds to generate secure streams of income to support their institutional mission, often by investing in conventional ways, using transparent publicly traded securities, such as stocks, bonds, and highly liquid money-market instruments (Humphreys et al., 2010). In addition, endowments protect universities from short-term economic pressures and allow freedom for the institutions more significant control over how to use assets (The Sutton Trust, 2014). Hence, one of the main operating goals of the endowments has been smoothing the institutional operating revenues to maintain the business operations' target level. More precisely, educational institutions build and maintain endowments to supplement and protect against declines in net tuition and fee revenues, state appropriations, and other income (Association of Governing Boards of Universities and Colleges, 2019). American Council on Education (2021) summarises four primary purposes of the universities 
and colleges endowments: (1) providing the stability of the revenues, (2) leveraging other sources of revenue, (3) encouraging innovation and flexibility, and (4) allowing a longer time horizon ensuring the long-term well-being of colleges and universities. Furthermore, Filosa (2021) points that in addition to providing annual revenue, the endowment offsets long-term liabilities and often is a source of liquidity to support debt costs, ratings, and covenants. Thus, the endowments have far-reaching goals for the institutions they serve:

\section{Method}

The endowments have different missions, strategic and operating goals. Therefore, except for the traditional measure - the financial assets' size - there is no unique and perfect metric valid for all endowments. In addition, solely the size of the financial assets generally represents the poor metrics for measuring effectiveness for any investment vehicle. Therefore, commonly, the size of the assets is accompanied by the other measures, or it is standardised with other parameters (e.g., size of the endowment assets related to the size of the debt of beneficiary institution).

Other academic endowments' performance indicators may be more tempting, e.g., investment performance measures such as the annual returns on the financial assets and risk-adjusted returns. However, although practical, such measures evaluate only the success of the investment strategy but neglect the achievement of spending strategy and even fundraising strategy. (Note 7) Moreover, some reports criticised and questioned the investment in endowments during the global financial crisis between 2007 and 2009. By engaging in speculative trading tactics, using exotic derivatives, deploying leverage, and investing in opaque, illiquid, over-crowded asset classes such as commodities, hedge funds, and private equity, endowments played a role in magnifying certain systemic risks in the capital markets (Humphreys et al., 2010). Thus, evaluating the endowments' performance and success, particularly in the educational sector, with proper performance measures is far more challenging.

Evaluation of the endowments' accomplishments requires specific performance measures. Particularly for the academic endowments, conventional indicators are (1) the size of the endowment per student and (2) the size of the endowment relative to the total expenditures of the institution. However, according to the Association of Governing Boards of Universities and Colleges (2019), at minimum, two elements are essential to assessing an endowment's effectiveness: (1) the percentage of an institution's revenue mix that is provided by the endowment, and (2) how well the allocation of endowment accounts aligns with current and anticipated spending priorities. In addition, some other helpful measures for academic endowments are: (1) endowment dependence that measures the role of the endowment in the annual institution budget, (2) endowment distribution to financial aid that compares endowment spending to the institution's financial aid and scholarship discounts to students, (3) endowment to debt that focuses on balance sheet health and the ballast the endowment provides for borrowing, and (4) net flow which is the ratio of endowment inflows to endowment spending (Filosa, 2020). Ultimately, the real worth of any endowment depends on how well those assets are managed and applied to work of value to society (Association of Governing Boards of Universities and Colleges, 2019).

In the following table, we outline the academic endowments' standard performance measures, including general measures of the investment performance (absolute return and risk-adjusted return).

Table 1. Performance measures of the academic endowments

\begin{tabular}{|c|c|c|}
\hline & Performance measure & Explanation \\
\hline 1 & $\begin{array}{l}\text { The size of the financial assets under } \\
\text { management }\end{array}$ & $\begin{array}{l}\text { Measure the share and strength of the endowment in the } \\
\text { endowment peer group }\end{array}$ \\
\hline 2 & The average annual returns & Measure the absolute investment performance \\
\hline 3 & The risk-adjusted returns & Measure the relative, risk-adjusted investment performance \\
\hline 4 & The size of the endowment per student & Measure the relative size of the endowment \\
\hline 5 & $\begin{array}{l}\text { The size of the endowment relative to } \\
\text { institution total expenditure (expenses) }\end{array}$ & $\begin{array}{l}\text { Measure the significance of the endowments in covering } \\
\text { institution expenditures (expenses) }\end{array}$ \\
\hline 6 & $\begin{array}{l}\text { The percentage of an institution's revenue mix } \\
\text { that is provided by the endowment (the ratio of } \\
\text { the annual endowment distribution to the } \\
\text { operating budget) }\end{array}$ & $\begin{array}{l}\text { Measure the importance of the income from the endowment } \\
\text { in total income and dependence and endowment's } \\
\text { contribution to the operating health of the institution }\end{array}$ \\
\hline 7 & The alignment of the allocation of endowment & Measure the alignment of the investment and spending tactics \\
\hline
\end{tabular}


accounts with current and anticipated spending priorities

Endowment spending to the institution's

8 financial aid and scholarship discounts to students

9 The size of the endowment relative to institution debt

10
Measures the endowment role in financial support for scholarships

Measure the relative wealth of the institution, including debt, i.e., balance sheet health and the ballast the endowment provides for borrowing

Measures the endowment capacity of spending covered by the endowment income

The following section provides and analysis specific performance measures for UK universities and colleges, excluding the investment performance. It will focus on the endowments 'performance relative to certain institutions' fundamentals (e.g., comparing the number of students). The analysis relies on the public data provided by the HESA (Higher Education Statistics Agency) and the data provided by the Charity Commission for England and Wales. The data were analysed using descriptive statistics. Our results are displayed graphically to highlight specific patterns.

\section{The Analysis and Discussion}

The university and college endowments in the UK, compared to the US, are of a lesser size.

Table 2. Performance measures of the academic endowments

\begin{tabular}{|c|c|c|c|}
\hline University \& Colleges & Endowment size & Number of & Endowment size \\
\hline University of Oxford (incl. colleges) & $6,354.1$ & 25,910 & 245,239 \\
\hline University of Cambridge (incl. colleges) & $5,476.0$ & 21,340 & 256,605 \\
\hline University of Edinburgh & 487.8 & 35,375 & 13,789 \\
\hline King's College London & 252.3 & 33,110 & 7,619 \\
\hline The University of Reading & 250.7 & 18,735 & 13,381 \\
\hline University of Manchester & 220.5 & 40,485 & 5,447 \\
\hline London School of Economics and Political Science & 198.4 & 12,050 & 16,466 \\
\hline University of Glasgow & 177.2 & 32,465 & 5,458 \\
\hline Imperial College of Science, Technology and Medicine & 176.0 & 19,400 & 9,073 \\
\hline University of Liverpool & 168.3 & 29,600 & 5,687 \\
\hline University College London & 143.2 & 41,095 & 3,485 \\
\hline University of Birmingham & 116.7 & 35,760 & 3,263 \\
\hline University of St Andrews & 95.6 & 10,535 & 9,072 \\
\hline University of London (Institutes and activities) & 88.3 & 330 & 267,518 \\
\hline University of Durham (excl. Colleges) & 86.4 & 19,520 & 4,427 \\
\hline University of Leeds & 82.1 & 36,330 & 2,261 \\
\hline Newcastle University & 80.0 & 28,070 & 2,850 \\
\hline Royal Holloway and Bedford New College & 78.8 & 11,530 & 6,832 \\
\hline University of Bristol & 78.7 & 27,375 & 2,875 \\
\hline The Prince's Foundation & 69.9 & 25 & $2,795,440$ \\
\hline Queen's University Belfast & 63.8 & 24,915 & 2,562 \\
\hline University of Nottingham & 62.3 & 34,840 & 1,789 \\
\hline London Business School & 59.5 & 2,305 & 25,810 \\
\hline University of Aberdeen & 51.9 & 15,185 & 3,420 \\
\hline
\end{tabular}

Source: Authors' calculation based on data provided by the Higher Education Statistics Agency and financial statements of the UK universities and colleges as of 30 June 2020. 
Table 2 provides the list of 24 UK higher education providers with endowments bigger than $£ 50$ million. (Note 8 ) For example, only two universities in the UK have endowment assets of over $£ 1$ billion (The University of Oxford and The University of Cambridge with college members). Other 22 higher education providers have endowments from $£ 50$ million and less than $£ 1$ billion. In contrast, in the US exist 110 endowments with assets of $\$ 1$ billion or more (most prominent being Harvard University, University of Texas System, Yale University endowment, and Stanford University), and the average endowment size is $\$ 905$ million. (Note 9)

According to some estimates, the assets under management of the endowments of the UK higher education providers are estimated to be $£ 16.3$ billion, with Cambridge and Oxford holding $80 \%$ of them (Tribe Impact Capital LLP, 2020). However, this amount and share are slightly overestimated. (Note 10) The size of the two most significant endowments as of 2020 is close to $£ 12.0$ billion, making their share $75 \%$ (Figure 1). As shown in Figure 1, this share has been constant over the previous years. Thus, the UK academic endowments universe is overwhelmed by a few substantially large endowments.

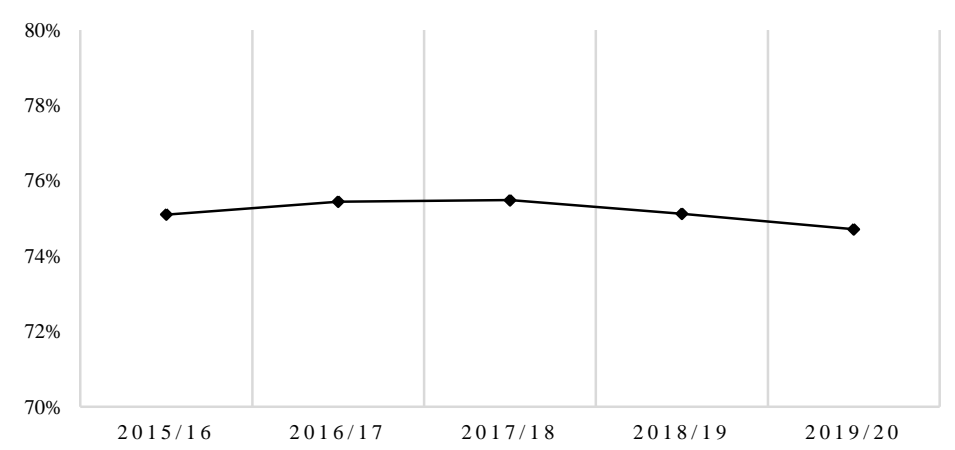

Figure 1. The share of the endowments of the University of Oxford and the University of Cambridge in the total size of the UK academic endowments

Source: Authors' calculation based on data provided by the Higher Education Statistics Agency and financial statements of the UK universities and colleges

One of the standard measures of the endowments significance for the academic institution is the relative size measured by the endowment size per student. Although, this metric has serious drawbacks when comparing institutions with different missions, locations, and business models (Association of Governing Boards of Universities and Colleges, 2019).

Excluding the two major UK academic institutions having an endowment of $£ 250$ thousand per student, other institutions have much smaller endowments, not exceeding the $£ 20$ thousand per student (Table 2). (Note 11) In comparison, the 2020 NACUBO-TIAA study of US and Canadian endowments (NTSE) shows that 17 US academic endowments achieve endowment size per student more than $\$ 1$ million. (Note 12) Compared to the most prominent UK academic institutions, the US universities and colleges have much larger endowments and greater financial autonomy. In addition, they have more freedom in attracting bright students irrespective of their financial capabilities.

The universities and colleges have several income sources (Figure 2). Therefore, the percentage of an institution's revenue mix provided by the endowment measures the importance of the income from the endowment in total income. Higher the share, the higher the endowment role in supporting the budget. If the income from the endowment is the largest source of revenue, the institution is more dependent on the long-term investment portfolio than student revenues (Filosa, 2020).

As shown in Figure 2, the basic income comes from tuition fees and education contracts that make up nearly half of the total income. Research grants and contracts follow them, making $16 \%$ to $17 \%$ of the total income in the last six years. The funding body grants make the third most vital income source in $14 \%$ of the total income.

The income from endowments represents the less critical revenue source. Over the period $2014-2020$, donations and endowments represented $1.6 \%$ to $2.2 \%$ of the total income of universities and colleges (Figure 3). However, this 
may underestimate the importance of the endowment a bit as they can make a significant difference for some academic institutions. Their importance relies on providing a reliable long-term income source for their beneficiaries. Additionally, their role in attracting the most brilliant students without solid financial backgrounds is of paramount importance. This ratio may be relatively large for some academic institutions, while it makes only a tiny part of the annual budget for the others. Only two higher education providers achieve this ratio greater than $10 \%$ (the London School of Economics and Political Science 13.9\% and the London Business School 11.6\%). However, certain reports question the endowments role and perhaps conceivably criticize their insufficient effort to reduce the reliance on student revenue and thus the cost of a college education (Filosa \& Prout, 2017).

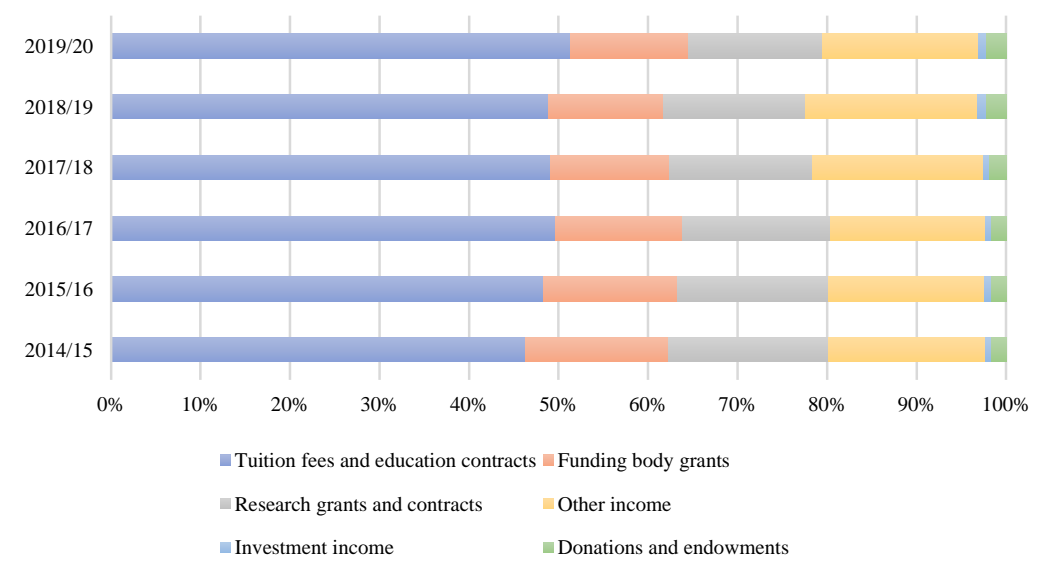

Figure 2. Income structure from the high education providers

Source: Authors' calculation based on data provided by the Higher Education Statistics Agency and financial statements of the UK universities and colleges.

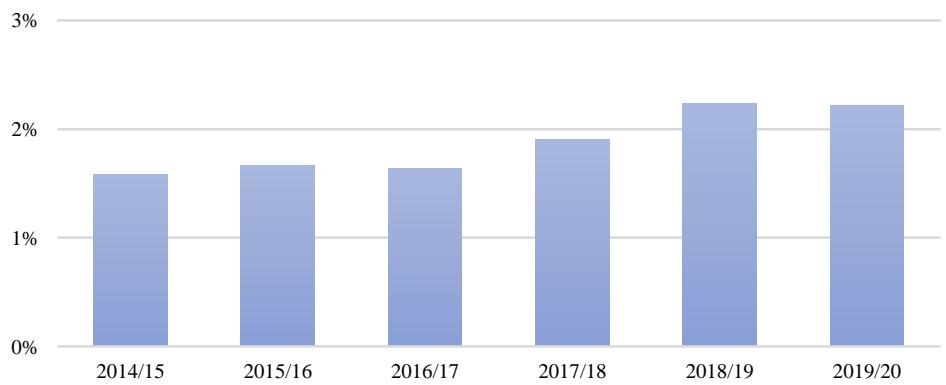

Figure 3. Income structure from the high education providers

Source: Authors' calculation based on data provided by the Higher Education Statistics Agency.

For most universities and colleges, tuition revenue is the largest source of income. Therefore, one of the purposes of the endowments is to provide financial support for scholarships. 


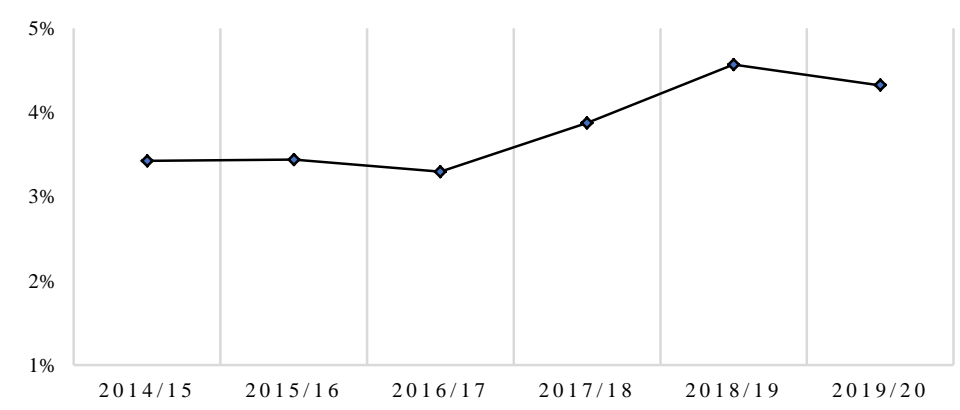

Figure 4. The ratio of income from donations and endowments and tuition fees and education contracts Source: Authors' calculation based on data provided by the Higher Education Statistics Agency

Figure 4 shows the ratio of the endowments and donations income and tuition and education contracts. Over the period 2015 to 2020 , this ratio rose from $3.4 \%$ in 2015 to $4.6 \%$ and $4.3 \%$ in recent two years, respectively. Thus, the absolute and relative significance of the income from endowments (and donations) has increased over time (Figure 2 and Figure 3, respectively). When the endowment income is substantial, it can generally provide more income flexibility, particularly with the tuition fees policy.

The endowment assets also have the role of supporting the universities' and colleges' balance sheets. The endowment offsets long-term liabilities, and often endowment capital is a source of liquidity to support debt costs, ratings, and covenants (Filosa, 2021). The greater the ratio of endowment assets to institution debt, the greater is endowment support to institution balance sheet health. When this ratio is too low, debt management becomes more critical, impacting borrowing costs. In addition, this could also limit the growth potential of the endowment portfolio by constraining investment strategy because strategies that reach for growth may also increase volatility (fluctuations in market value) and illiquidity (private investments). It could trip debt covenants, threaten the debt rating, and increase the cost of borrowing (Filosa, 2021).

Figure 5 depicts the size of the endowments, total creditors, and ratio of endowment reserve and creditors. According to data from HESA, throughout 2015/16 to 2019/20, the ratio of endowment reserve and total debt for all higher education providers in the UK for 2020 has a downward slope, reaching the bottom of $21.9 \%$ in last year. (Note 13) In general, this suggests that over the period 2015/16 to 2019/20, the total debt has been accelerated more than the endowment's assets of the universities and colleges, resulting in a lower coverage ratio.

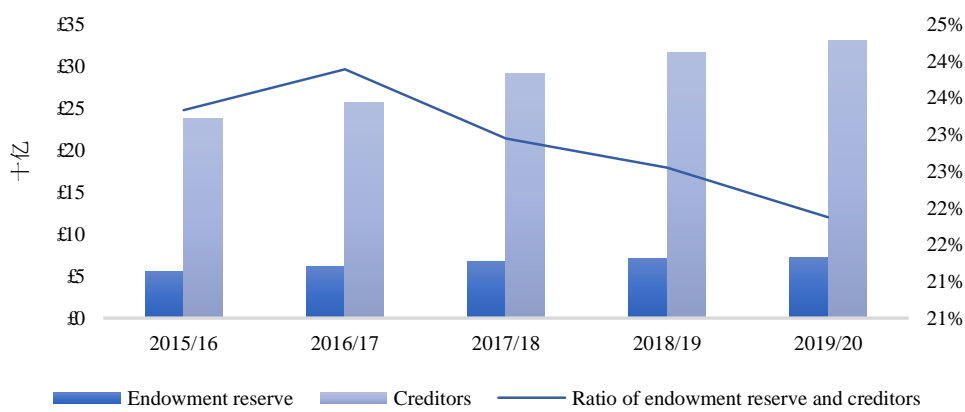

Figure 5. The ratio of income from donations and endowments and tuition fees and education contracts Source: Authors' calculation based on data provided by the Higher Education Statistics Agency

For the most reputable UK academic universities and colleges, the role of the endowments in providing a healthy income stream and strong balance sheet has been substantial over the years, although with much less degree than US academic institutions. However, the endowments have played a less significant role for many other UK academic 
institutions.

\section{Conclusion}

The paper aimed to understand better the role and significance of the endowments in the UK higher education system through endowments` performance metrics. The analysis uses the data provided by the HESA (Higher Education Statistics Agency) and the data provided by the Charity Commission for England and Wales.

The impact of the academic endowments may be significant for the national higher education system in general and particularly for some highly reputable academic institutions. However, in contrast to endowments linked with US academic institutions, the UK endowments have less significance for the UK higher education system. On average, they are much smaller in total and relative size measured by the endowment size per student.

The UK universities and colleges endowments size is estimated to amount to $£ 15.8$ billion in 2020. However, there is a notable difference concerning endowment size among the academic institutions. For example, the two largest endowments (the University of Oxford and the University of Cambridge with accompanied colleges endowments) in 2020 had a share of $75 \%$ measured by the size of the endowment assets with an almost constant ratio over the last several years.

The income from endowments represents a relatively small revenue source for UK academic institutions. Over the period $2014-2020$, donations and endowments represented $1.6 \%$ to $2.2 \%$ of the total income of universities and colleges. For some institutions, this ratio is higher. However, only two higher education providers achieve this ratio greater than 10\% (the London School of Economics and Political Science 13.9\% and the London Business School $11.6 \%)$.

The endowment assets also play the role of supporting the universities' and colleges' balance sheets. The greater the ratio of endowment assets to institution debt, the greater is endowment support to institution balance sheet health. According to data from HESA, throughout 2015/16 to 2019/20, the ratio of endowment reserve and total debt for all higher education providers in the UK for 2020 has a downward slope, reaching the bottom of $21.9 \%$ in last year. Over the period 2015/16 to 2019/20, the total debt has been accelerated more than the endowment's assets of the universities and colleges, resulting in a lower coverage ratio.

This paper brings practical implications. First, it helps to understand the role and significance of endowments in the UK higher education system. The analysis suggests significant growth potential for a number of universities and colleges with smaller endowments with a minor contribution to their operating budget. Secondly, the larger endowments ensure a prominent role for the academic institutions and financially support their high reputation.

However, our research has certain limitations: the results are not necessarily generalizable to the other countries` higher education systems. Therefore, a deeper investigation of this topic could be conducted using a broader sample of higher education systems to understand better the factors affecting the impact of the academic endowments.

\section{References}

American Council on Education. (2021). Understanding College and University Endowments.

Arts Council England. (2010). Endowments in the arts. Retrieved from http://www.artscouncil.org.uk/media/uploads/doc/final_endowments_in_the_arts.pdf

Association of Governing Boards of Universities and Colleges. (2019). The Worth of Endowments in Higher Education.

Chambers, D., \& Dimson, E. (2015). The British origins of the US endowment model. Financial Analysts Journal, 71(2), 10-14. https://doi.org/10.2469/faj.v71.n2.7

Filosa, T. A. (2020). Endowment Radar Plotting the Role of the Endowment.

Filosa, T. A. (2021). Endowment Radar Study 2020.

Filosa, T., \& Prout, W. (2017). Can College and University Endowments Do More?. (Issue April).

Franz, R., \& Kranner, S. (2019). University Endowments - A Primer. CFA Institute Research Foundation Briefs. https://doi.org/10.4135/9781483346595.n298

Hammond, D. (2020). A better approach to systematic outperformance? 58 years of endowment performance. Journal of Investing, 29(5), 6-30. https://doi.org/10.3905/joi.2020.1.138

Humphreys, J., Electris, C., Fapohunda, Y., Filosa, J., Goldstein, J., \& Grace, K. (2010). Educational Endowments and the Financial Crisis: Social Costs and Systemic Risks in the Shadow Banking System. 
Maginn, J. L., Tuttle, D. L., McLeavey, D. W., \& Pinto, J. E. (2007). Managing Institutional Investor Portfolios. In Managing investment portfolios: a dynamic process (3rd ed., pp. 63-127). JohnWiley \& Sons, Inc., Hoboken, New Jersey.

Philanthropy in America A Comprehensive Historical Encyclopedia. (2004). In D. F. Burlingame (Ed.), Princeton University Press. ABC-CLIO, Inc.

The Sutton Trust. (2014). Academic Assets University Fundraising - An Update (Issue June).

Tribe Impact Capital LLP. (2020). University endowments in 2020.

Universities UK. (2019). Statement of Recommended Practice.

\section{Notes}

Note 1. In the paper, expressions ,academic endowments“, „university and college endowments“, and „endowments of the higher education providers" will be used interchangeably.

Note 2. Data are collected on 14 December 2021 from register of charities provided by the Charity Commission for England and Wales (Retrieved from: https://register-of-charities.charitycommission.gov.uk).

Note 3. The author`s estimation is based on the higher education providers' financial statements (as of 30 June 2020).

Note 4. According to Chambers \& Dimson (2015), British economist John Maynard Keynes have had a considerable influence on the US endowment model, approach popularized by Yale University that emphasizes diversification and active management of equity-oriented, illiquid assets. In addition, the oldest Cambridge college, Peterhouse, was endowed in the late 13th century; King's, in the mid-15th century. An Encyclopedia of Philanthropy in America states that John Harvard in 1638 bequeaths his library and half of his estate to newly founded (1636) Harvard College at Cambridge, Massachusetts. During the period 1715 - 1718 Elihu Yale sends gifts to Collegiate School of Connecticut (chartered 1701); in 1718, the school changes its name to Yale College (Philanthropy in America A Comprehensive Historical Encyclopedia, 2004).

Note 5. There are some noticeable similarities and differences between endowments and foundations. Although both are created by donations, foundations and endowments usually develop differently over time. Private foundations typically are created and funded by a single donor to fund philanthropic goals. The investment portfolio provides the dominant source of revenue, and the purchasing power is either maintained or eventually given away. Endowments, by contrast, are often built up over time by many individual gifts to the endowed institution. Spending distributions are determined by the beneficiary institution, supplementing other revenue sources such as tuition, grants, fees, or gifts for current use. In contrast to private foundations, endowments are not subject to a specific legally required spending level (Maginn et al., 2007).

Note 6. In 2019 Cambridge University has received its most significant ever gift, a $£ 100$ million donation from the David and Claudia Harding Foundation (https://www.cam.ac.uk/news/cambridge-university-secures-unprecedented-ps100-million-gift-to-support-students). The Moody Foundation has granted Rice University $\$ 100$ million to build a transformative new student center designed by one of the world's premier architects and to create endowments supporting student opportunity and success, both as part of the center and in other areas of the university (https://news.rice.edu/news/2021/moody-foundation-grants-100-million-rice-university).

Note 7. For more details on evaluating the investment performance of the endowments see: (Hammond, 2020).

Note 8. The list also includes the University of London (Institutes and activities) and The Prince's Foundation as a higher education provider. The University of London University of London is a federation of 17 member institutions (https://www.hesa.ac.uk/support/providers/uol-members). The Prince's Foundation was created through the merger, in 2018, of The Prince's Foundation for Building Community, The Prince's Regeneration Trust, The Great Steward of Scotland's Dumfries House Trust and The Prince's School of Traditional Arts (https://princes-foundation.org/about).

Note 9. Source: The National Association of College and University Business Officers (2021). For example, the most considerable endowment value has Harvard University with an astonishing $\$ 40.6$ billion, over five times bigger than the endowment of the University of Oxford, including member colleges. Some sources report Harvard University endowment value of $\$ 41.9$ billion at the end of the fiscal year 2020 (https://www.usnews.com/education/best-colleges/the-short-list-college/articles/10-universities-with-the-biggest-end 
owments).

Note 10 . The author`s calculation is closer to $£ 15.8$ billion.

Note 11. We exclude the University of London (Institutes and activities) with 330 registered students and the Prince's Foundation with 25 students.

Note 12. FY20 Endowment Value Per Full-time Equivalent Student (\$). Source: The National Association of College and University Business Officers (2021).

Note 13. This ratio does not account for endowments reserves and debt of colleges, members of the University of Oxford and University of Cambridge. Their endowment reserves are substantial, £3.5 billion, and £5.1 billion respectively.

\section{Copyrights}

Copyright for this article is retained by the author(s), with first publication rights granted to the journal.

This is an open-access article distributed under the terms and conditions of the Creative Commons Attribution license (http://creativecommons.org/licenses/by/4.0/). 